\title{
The Columbus Container Services ECJ Case and Its Consequences: A Lost Opportunity to Shed Light on the Scope of the Non-discrimination Principle
}

\author{
Jose Calderón, Andrés Baez*
}

\begin{abstract}
This article examines the European Court of Justice's (ECJ's) judgment in the Columbus Container Services BVBA \& Co. v. Finanzamt Bielefeld-Innenstadt (bereinafter 'Columbus Container Services') case (C-298/05). After a brief description of the facts and the decision, the authors critically analyze the ruling, in light of potential acceptance of horizontal comparability as opposed to the traditional migrant/non-migrant approach of the ECJ. A study of the ECJ's case law on horizontal pairs of comparison, together with a possible legal background for this approach (single market principle), allows the authors to conclude that the German rules under scrutiny (switch-over clause in quasi-CFC situations) were in breach of fundamental freedoms. Finally, the authors also consider hypothetical consequences of Columbus Container Services for other problems at stake such as the future of anti-avoidance rules in the European context, rules on classification of foreign entities, consolidation regimes that might imply treaty overrides, or the compatibility of the credit method itself with EC law.
\end{abstract}

\section{SCope of This Paper}

On 6 December 2007, the European Court of Justice (ECJ) delivered its ruling in the case of Columbus Container Services BVBA \& Co. v. Finanzamt Bielefeld-Innenstadt (hereinafter 'Columbus Container Services'). ${ }^{1}$ The case had awakened the interest of scholars before the judgment. ${ }^{2}$ Nevertheless, the decision has created new uncertainties not only because it did not answer crucial questions on the facts ${ }^{3}$ but also because it seems to have apparently changed - or at least modulated - prior decisions of the ECJ. This paper will specially focus on these silences and inconsistencies.

In the first section, we will briefly describe the facts and the ECJ's judgment. After that, we will consider the ruling in a critical way, applying to the case the basic elements usually managed by the ECJ in its non-discrimination case law and exposing our position that substantially differs from that held by the Court (section 3). Even if we do not share the reasoning and conclusions of the ECJ, we will consider the hypothetical consequences of Columbus Container Services for other problems at stake, such as rules on classification of foreign entities, consolidation regimes that might imply treaty overrides, or the compatibility of the credit method itself with EC law (section 4).

\section{Columbus Container Services: The FACTS AND THE RULING}

Columbus Containers BVBA \& Co. is a limited partnership governed by Belgian law whose object comprises the coordination (finance, marketing, management, and bookkeeping) of the activities performed by an international group. Its shares were held by eight natural persons residing in Germany (80\%) and a German partnership (20\%) whose partners also resided in Germany.

According to Belgian law, Columbus is a taxable person falling under the scope of the 'coordination centre' regime that grants far-reaching tax advantages. On the other hand, under German tax law, Columbus was treated as a transparent partnership and its profits were assigned to the partners residing in Germany.

\section{Notes}

Jose Calderón is Professor at the University of La Coruña, and Andrés Báez is Professor at the University Carlos III and Public University of Navarra. The authors can be contacted at the following e-mail addresses: <taxesp@udc.es and abaez@der-pu.uc3m.es>. The research for this article was conducted under project SEJ2006-00159JURI ('La armonización de la imposición sobre Sociedades') directed by Prof. J. Zornoza (Carlos III University of Madrid) and financed by the Spanish Ministry of Education and Science.

Case No. C-298/05, Columbus Container Services BVBA \& Co. v. Finanzamt Bielefeld-Innenstadt.

Lüdickeüdicke, 'Pending cases Filed by German Courts I: The Meilicke, CLT-UFA, Keller Holding, Lasertec, Rewe Zentralfinanz, Ritter-Coulais, Kolumbus Contaniner Services, and Stauffer Cases', in ECJ: Recent Developments in Direct Taxation (Wien: Linde, 2006), 163-168; Cordewener, 'EC Law Protection against "Horizontal" Tax Discrimination on the Rise - or How to Play Snooker in an Internal Market' EC Tax Review no. 5 (2007), 211; Lang, 'Die Zukunft der Doppelbesteuerungsabkommen im Lichte von Columbus Container', in Festschrift fïr Wolfram Reiss: zum 65. Geburtstag' (Köln: Otto Schmidt, 2008), 679-696; Cordewener, 'German Anti-avoidance Measures versus Belgian Coordination Centres: A Long Struggle without Survivors?', in A vision of Taxes Within and Outside European Borders. Festschrift in Honour of Prof. Dr. Frans VAnistendael (Alphen aan den Rijn: Kluwer, 2008), 228-232.

Farmer considers the ruling to be disappointing on avoiding completely certain key issues: Farmer, 'Columbus Container Services BVBA E Co. v. Finanzamt Bielefeld-Innenstadt: The ECJ Fails to Grasp the Tax Competition Nettle in Relation to Foreign Income Rules', British Tax Review no. 2 (2008), 106. 
Under the Belgium-Germany tax treaty, Germany applies the exemption method for income derived from capital invested in a Belgian limited partnership. Germancontrolled foreign corporation (CFC) rules (sections 7 to 14 Außensteuergesetz; Foreign Tax Act) do not cover branch profits. In order to avoid possible circumvention of these rules, section 20 (2) of the Foreign Tax Act contains a special provision that taxes foreign permanent establishments with passive investment income in low-tax jurisdictions applying the credit method rather than by way of exemption.

German tax authorities applied these provisions, and Columbus challenged the decision before the Courts. The Finanzgericht Münster referred the case to the ECJ for a preliminary ruling asking whether Articles 43 and 56 EC must be interpreted as precluding tax legislation of a Member State under which the income of a resident national derived from capital invested in an establishment having its registered office in another Member State is, notwithstanding the existence of a double taxation convention (DTC) concluded with the Member State in which that establishment has its registered office, not exempted from national income tax but is subject to national taxation against which the tax paid in the other Member State is set-off.

The ECJ first stated that the situation under consideration was covered by the treaty provisions on the freedom of establishment. ${ }^{4}$ After this, the Court analyzed the hypothetical restriction on the fundamental freedom but just answering one of the questions usually raised in relation to it. Preliminary rulings concerning direct taxation and EU fundamental freedoms usually imply two questions: does an internal provision restrict the exercise of a fundamental freedom, and, in that case, is the restriction justified?

However, as stated before, the ECJ avoided the second question by simply refusing the existence of a restriction in the case referred. The Court indicated that the German switch-over clause had made no distinction between taxation of income from a domestic partnership and from a partnership residing in a different Member State. ${ }^{5}$ By means of this vertical analysis (migrant/non-migrant test), the ECJ declined to apply the horizontal approach, which had been suggested by AG Mengozzi. ${ }^{6}$ This reflection saved the ECJ from having to consider the difficult task of a possible justification for German rules under analysis.

The ruling finishes with several obvious and perhaps unnecessary statements. It states that the Court has no jurisdiction to rule on the possible infringement of the provisions of double tax conventions by a contracting
Member State. Following the Advocate General's (AG's) Opinion, the ECJ states that it may not examine the relationship between a national measure, such as that in issue in the main proceedings, and the provisions of a DTC, such as the Bilateral Tax Convention, since that question does not fall within the scope of Community law. ${ }^{7}$

\section{Critical Revision: Horizontal Comparability AND Justification Test}

It is obvious that the issue of comparability constitutes a previous question in Columbus Container Services and, we might say, in any pronouncement related to virtual restrictions on European fundamental freedoms. As we have seen, if two cross-border situations are not considered to be comparable, no restriction analysis will be wise. If, on the other hand, a horizontal test is to be applied, we may find a restriction on fundamental freedoms and, in that case, a justification analysis will be pertinent. In this section, we will try to develop this two-step analysis, dealing with the question of possible justifications for the restrictions that the ECJ left unanswered.

\section{I. Vertical and Horizontal Non-discrimination}

The question of whether EC law protects against horizontal tax discrimination may be considered crucial in two different points of view. On the one hand, and specially referring to Columbus Container Services, a strict vertical comparison approach precludes further analysis on the case. On the other hand, its acceptance might partly redefine the very concept of non-discrimination, ${ }^{8}$ although not with the effects that have been sometimes described.

As stated before, the ECJ easily rejected horizontal comparability bringing up the migrant/non-migrant test as described in Mark Kerckhaert and Bernadette Morres $v$. Belgische Staat (hereinafter 'Kerckhaert-Morres').' According to this, German tax legislation does not make any distinction between taxation of income derived from the profits of partnerships established in Germany and taxation of income derived from the profits of partnerships established in another Member State, which subjects the profits made by those partnerships in that State to a rate of tax below $30 \%$. By applying the set-off method to such foreign partnerships, that legislation merely subjects, in

\section{Notes}

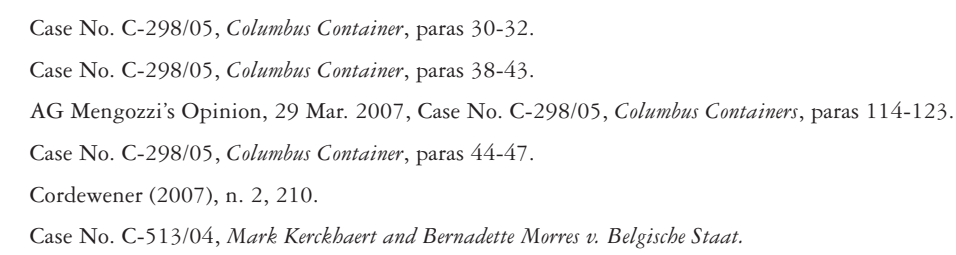


Germany, the profits made by such partnerships to the same tax rate as profits made by partnerships established in Germany. And, consequently, since partnerships such as Columbus do not suffer any tax disadvantage in comparison with partnerships established in Germany, there is no discrimination resulting from a difference in treatment between those two categories of partnerships. ${ }^{10}$ When confronted with the submission of Columbus that the provisions of the $A S t G$ lead to a distortion of the choice that companies and partnerships have to establish themselves in different Member States, the ECJ merely answers that Member States enjoy a certain autonomy and it follows from that tax competence that the freedom of companies and partnerships to choose, for the purposes of establishment, between different Member States in no way means that the latter are obliged to adapt their own tax systems to the different systems of tax of the other Member States in order to guarantee that a company or partnership that has chosen to establish itself in a given Member State is taxed, at national level, in the same way as a company or partnership that has chosen to establish itself in another Member State. ${ }^{11}$

In order to ascertain whether a horizontal approach might be fitting for a case such as the Columbus Container Services, we will consider several issues. First, we should (1) consider the special importance given by the ECJ to the 'Kerckhaert-Morres approach' when dealing with a case such as the Columbus Container Services. After that, we will (2) weigh the pros and the cons of horizontal comparability considering the special virtues of this non-discrimination approach, (3) analyzing if and, in case, to what extent it has been admitted by the ECJ's case law.

\section{I.I. Kerckhaert-Morres and Horizontal Comparability}

As stated before, the ECJ in Columbus Container Services made wide use of the reflections contained in KerckhaertMorres, putting forward that German tax legislation in issue was comparable in this respect to the Belgian tax legislation that was applied in the former case. ${ }^{12}$ Also, a large number of authors have stressed the strong resemblance to Columbus Container Services. ${ }^{13}$

In Kerckhaert-Morres, the ECJ considered Belgian dividend taxation rules under the free movement of capital provision contained in the EC Treaty. These rules made dividends from shares in companies established in Belgium and dividends from shares in companies established in another Member State subject to the same uniform rate of taxation. Nevertheless, Belgium did not provide for the possibility of setting off the tax levied by deduction at source in France, overriding thereby the Belgium-France DTC. The ECJ, applying a migrant/non-migrant test, considered that the adverse consequences that might arise from the application of an income tax system such as the Belgian system resulted from the exercise in parallel by two Member States of their fiscal sovereignty.

According to this description, we do not consider that Columbus Container Services and Kerckhaert-Morres are to be considered similar or comparable cases. As we have already stated, the most complicated issue in Columbus Container Services is determining whether or not two crossborder situations may be considered comparable, providing thereby a possibility to consider the existence of a restriction of fundamental freedoms. Obviously, applying case law based upon vertical comparison considerations to Columbus Container Services seems totally incongruous. In the last two decades, the ECJ jurisprudence on direct taxation and treaty freedoms has been changing and broadening its scope. Initially referred to so-called inbound situations' (source state treatment of non-residents), the Court had to deal relatively early with 'outbound situations' (home state treatment of residents performing cross-border activities). To deny the existence of a restriction in an outbound situation, applying 'inbound case law', would have been so inconsistent as it is refusing horizontal comparability on a migrant/non-migrant test approach. The Court should have analyzed the consistency of the horizontal comparability within treaty freedoms instead of ignoring the problem by using a concept that is not directly related to the case.

There is a last issue that must be analyzed in relation to this problem. Kerckhaert-Morres is not the only ruling referring to the migrant/non-migrant test (vertical approach). Rather, the opposite is true. In relation to direct taxation, all cases, except for those dealing with horizontal discriminations, have to be based upon a classical migrant/non-migrant approach. Why then such an insistence on Kerckhaert-Morres, which is merely an example of this vertical approach? In our opinion, there is just a single similarity between Columbus Container Services and Kerckhaert-Morres: the existence of a treaty override. But this point in common does not allow to simply transfer the solution of Kerckhaert-Morres to Columbus Container Services. It is not the treaty override itself that hypothetically constitutes a restriction of fundamental freedoms because even in a treaty override situation, it would be

\section{Notes}

10 Case No. C-298/05, Columbus Container, paras 39-40.

Ibid., paras 50-51.

Ibid., para. 39.

13 O'shea, 'German CFC Rules Held Compatible With EU Law', Tax Notes International (24 Dec. 2007), 1205, considering both rulings as 'analogous'. Kessler \& Eicke, 'The Egg of Columbus Container: German Budget Sunny Side Up, Not Scrambled', Tax Notes International 49, no. 7 (2008), 589; Meussen, 'Columbus Container Services A Victory for the Member States's Fiscal Autonomy', European Taxaion (Apr. 2008), 171, referring a significant resemblance to Columbus. 
different if the replacement of the exemption method by the set-off method applied irrespective of the rate at which the income in question was taxed in Germany. In that situation, any unfavourable treatment caused by the application of that method to similar income of German taxpayers derived from permanent establishments located abroad would depend essentially on the level of tax levied in each of the Member States. It would in that case be unfavourable treatment arising from the coexistence of the different tax legislations of the Member States. However, that is certainly not the case in Columbus Container Services. ${ }^{14}$

Our conclusion turns out to be the same: the acceptance of the comparability of cross-border situations and, therefore, of horizontal discrimination is the real point at stake in Columbus Container Services. ${ }^{15}$

\section{I.2. Horizontal Comparability and Horizontal Tax Discrimination: Is It Acceptable Under Theoretical Arguments?}

Horizontal comparability has become a controversial issue at the academic level in recent years. Nevertheless, the reflections on this problem have merely focused on the acceptance of this comparison in ECJ case law. In short, instead of discussing possible grounds for this particular approach, most authors analyze the evolution of the ECJ's case law on horizontal comparability studying if, and to what extent, this peculiar comparison has been admitted. ${ }^{16}$ We do not consider that these reflections must be ignored; nevertheless, in order to offer a proper solution for Columbus Container Services and similar cases, we should pay attention to possible theoretical pillars upon which horizontal comparability might be based.

Just AG's Opinions provide certain background in favour of horizontal comparability. So, AG Léger, in Cadbury Schweppes plc and Cadbury Schweppes Overseas Ltd v. Commissioners of Inland Revenue (hereinafter 'Cadbury Schweppes'), stated that not admitting this comparison would be tantamount to conceding that a Member State is entitled to choose the other Member States in which its domestic companies may establish subsidiaries with the benefit of the tax regime applicable in the host state. Such a situation would manifestly lead to a result contrary to the very notion of 'single market'. ${ }^{17}$ Following the same line of thought, AG Mengozzi suggests that national measures such as those referred to in Columbus Container Services and Cadbury Schweppes should be regarded as having the effect of fragmenting the common market by encouraging German nationals to establish themselves only in Member States where the level of taxation is equal to or above the German rate provided for in the $A S t G$. Some authors have also relied on the 'common/internal market argument', ${ }^{18}$ reinforcing it on the basis of a striking image provided by Frans Vanistendael. A prohibition with regard to restrictions on fundamental freedoms views the EU market as a whole where all economic actors can move from one end to the other. It views the EU market as a huge snooker table, where all the economic balls roll smoothly from one corner to the other. ${ }^{19}$

If, as generally stated, fundamental freedoms pursue one essential aim that is identified with the achievement of an EU-wide internal market, ${ }^{20}$ potential restrictions on fundamental freedoms must be considered taking this objective into account. In our opinion, it does not seem to be arguable that a different and selective treatment of identical, similar, or comparable cross-border activities might lead to fragmentation of the common market. In fact, the 'common market approach' has been used in legal writing in order to justify horizontal comparability in several situations. ${ }^{21}$

Once we have found a legal background for horizontal comparability, the moment has come to analyze its acceptance in the ECJ's case law.

\section{I.3. Case Law on Horizontal Comparability: Is It Recognized by the ECJ?}

The case law of the ECJ on cross-border situations' comparability has been said to be meager. ${ }^{22}$ In our opinion,

\section{Notes}

14 This is the position of AG Mengozzi's Opinion, 29 Mar. 2007, Case No. C-298/05, Columbus Containers, paras 129.

15 Other authors have also considered this the key issue of Columbus: Opinion Statement of the CFE (hereinafter 'CFE'), 3.

${ }_{16}$ This type of analysis might be found in Cordewener (2007), n. 2, n. 3, 210-212; Hohenwarter, 'The Allocation of Taxing Rights in the Light of the Fundamental Freedoms of EC Law', in Tax Treaty Law and EC Law, eds Lang, Schuch, \& Staringer (Vienna: Linde, 2007), 100-102; Kemmeren, 'The Internal Market Approach Should Prevail over the Single Country Approach', in A Vision of Taxes Within and Outside European Borders. Festschrift in Honour of Prof. Dr Frans Vanistendael (Alphen aan den Rijn: Kluwer, 2008), 575-576; Lang (2008), n. 2, 685-692.

17 AG Leger's Opinion, 2 May 2006, Case No. C-196/04, Case No. C-196/04, Cadbury Schweppes plc and Cadbury Schweppes Overseas Ltd v. Commissioners of Inland Revenue, para. 80 .

18 Cordewener \& Schnitger, 'Europarechtliche Vorgaben für die Vermeidung der internationalen Doppelbesteurung im Wege der Anrechnungsmethode', Steuer und Wirtschaft no. 1 (2006), 73; Cordewener (2007), n. 2, 211; Cordewener (2008), n. 2, 230

19 Vanistendael, 'The Compatibility of the Basic Economic Freedoms with the Sovereign National Tax Systems of the Member States', EC Tax Review (2003), 139.

20 Cordewener, 'The Prohibitions of Discrimination and Restriction within the Framework of the Fully Integrated Internal Market', in EU Freedoms and Taxation, ed. Frans Vanistendael (Amsterdam: IBFD, 2006), 4-5.

21 Kofler \& Schindler, 'Dancing with Mr D: The ECJ's Denial of Most-Favoured-Nation Treatment in the “D” Case', European Taxation, Dec. (2005), 531; Hohenwarter, n. 16, 120; Cordewener (2006), n. 20, 25; Cordewener (2007), n. 2, 211.

22 Hohenwarter, n. 16, 100 . 
the situation might be considered even worse; the real problem is not about lack of rulings but about lack of consistency in the case law. Therefore, we must consider different groups of rulings in which the ECJ has accepted or rejected horizontal comparability and check whether the case law is inconsistent and, in that case, why it is so.

The ECJ has considered a possible comparison of cross-border situations under the heading of three different points of view: the 'Principle of Neutrality of Legal Form', the 'most-favoured-nation treatment' (MFN), and the CFC (also quasi-CFC) legislation. ${ }^{23}$ We should briefly analyze these three groups of cases.

Horizontal reflections in the context of the principle of neutrality of legal form are not new. Already in Commission of the European Communities v. French Republic (hereinafter 'Avoir Fiscal'), ${ }^{24}$ the ECJ stated that the first paragraph of Article 52 of the Treaty expressly leaves traders free to choose the appropriate legal form in which to pursue their activities in another Member State and that freedom of choice must not be limited by discriminatory provisions. ${ }^{25}$ As it has been declared, at the very beginning, no importance was attached to this statement. ${ }^{26}$ Nevertheless, in subsequent cases such as Compagnie de Saint-Gobain, Zweigniederlassung Deutschland v. Finanzamt Aachen-Innenstadt (hereinafter 'Saint Gobain') ${ }^{27}$ and recently CLT-UFA S.A. v. Finanzamt Koln-West (hereinafter 'CLT$\left.U F A^{\prime}\right),{ }^{28}$ the ECJ adopted this same rationale. In our opinion, this vested case law on the principle of neutrality of legal form does not set a precedent in relation to horizontal comparability in cases such as the Columbus Container Services for the following reasons.

First of all, the principle of 'free choice of legal form' in the cases cited above refers to inbound investment situations. Its application to outbound situations, such as that analyzed in Columbus Container Services, is rather questionable. In some cases such as Marks E Spencer plc v. David Halsey (Her Majesty's Inspector of Taxes), the ECJ merely avoided the problem, ${ }^{29}$ which, by the way, could not pass unnoticed for the ECJ since AG Poaires Maduro, in his opinion, had explicitly rejected horizontal comparability. ${ }^{30}$ In other cases such as Columbus Container Services, the Court simply rejected the application of the principle, resorting to the fleeting concept of 'fiscal autonomy'. ${ }^{31}$ The reasons for this different approach to the principle of free choice of legal form, depending on the inbound or outbound character of the investment, remain unexplained. Nevertheless, the second argument in order to reject the acceptance of this principle as an embedded support for horizontal comparability might give a clue on this issue.

It is a common assumption among scholars that in cases such as the Avoir Fiscal, Saint Gobain, and CLT-UFA, the problem at stake could have been also resolved on the basis of the classical migrant/non-migrant test (that is, vertical pair of comparison). ${ }^{32}$ Effectively, these cases involved unfavourable treatment of branches in the host state, therefore, non-migrant situations, and could be resolved under the scope of a typical vertical approach.

In short, neither the acceptance of the principle of free choice of legal form in inbound situations nor its refusal for outbound investments sheds light on the acceptance of horizontal comparability by the ECJ.

Horizontal comparability in the ECJ case law has been also analyzed in regard to the issue of MFN treatment. Assuming that the essential core of the concept of MFN is that a state accepts an obligation not to discriminate against subjects of another state vis-a-vis subjects of a third state, ${ }^{33}$ some authors have drawn their conclusions in relation to horizontal comparability. The acceptance or refusal of MFN implies the corresponding acceptance or refusal of horizontal comparability. ${ }^{34}$ On the other hand, the acceptance of horizontal comparability in cases not directly related to the application of DTC's will open the door to MFN treatment. ${ }^{35}$ In our opinion, none of these statements can be shared.

\section{Notes}

23 Interesting summaries of this case law might be found in Hohenwarter, n. 16, 100-102; Cordewener (2007), n. 2, 210-211; Lang (2008) n. 2, 685-692.

24 Case No. C-270/83, Commission of the European Communities v. French Republic.

Ibid., para. 22.

26 Cordewener, Europäische Grundfreibeiten und nationales Steuerrecht. „Konvergenz" des Gemeinschaftsrechts und Kobärenz" der direkten Steuern in der Rechtsprechung des EuGH (Köln: Otto Schmidt, 2002), 831; Lang (2008), n. 2, 686.

27 Case No. C-307/97, Compagnie de Saint-Gobain, Zweigniederlassung Deutschland v. Finanzamt Aachen-Innenstadt.

28 Case No. C-253/03, CLT-UFA.

29 On this avoidance, see Lang, 'Gemeinschaftsrechtliche Verpflichtung zur Rechtsforneutralität im Steuerrecht?', Internationales Steuerrecht no. 12 (2006), 400-402; Lang, 'The Marks E Spencer Case - The Open Issues Following the ECJ's Final Word', European Taxation (Feb. 2006), 55-56.

30 Opinion dated 7 Apr. 2005, Case No. C-446/03, Marks \& Spencer plc v. David Halsey (Her Majesty's Inspector of Taxes), para. 49.

31 Case No. C-298/05, Columbus Container, paras 51-53.

32 Schön, 'The Free Chocie between the Right to Establish a Branch and to Set-up a Subsidiary - a Principle of European Business Law', European Business Organization Law Review 2 (2001), 358-359. Lang (2006), n. 29, 298; Schnitger, 'The CLT-UFA Case and the "Principle of Neutrality of Legal Form”', European Taxation, Dec. (2004), 525; Cordewener (2007), n. 2, 210-211; Hohenwarter, n. 16, 100-101. Lang, (2008), n. 2, 686, making reference just to Avoir Fiscal.

33 Cordewener \& Reimer. 'The Future of Most-Favoured-Nation Treatment in EC Tax Law - Did the ECJ Pull the Emergency Brake without Real Need? Part 1', European Taxation (Jun. 2006), 241.

34 Kemmeren, n. 16, 575-576.

35 Kessler \& Eicke, n. 13, 589-590. 
Of course, one could always claim that the denial of $\mathrm{MFN}$ in the case law of the $\mathrm{ECJ}^{36}$ was wrong because it was based on the questionable idea that persons covered by a tax treaty were per se incomparable with other persons. ${ }^{37}$ Nevertheless, the question of MFN is so far-reaching and complicated that its treatment in an article like this seems inappropriate. A better approach could be to analyze the pillars upon which the ECJ has denied a horizontal comparison in cases such as D. v. Inspecteur van de Belastingdienst (hereinafter ' $D$.') or Test Claimants in Class IV of the ACT Group Litigation v. Commissioners of Inland Revenue (hereinafter ' $A C T$ ') and to decide whether or not these may be suitable for every comparison between migrant situations.

The grounds offered by the ECJ in D. and ACT. are identical:

The fact that those reciprocal rights and obligations apply only to persons resident in one of the two Contracting Member States is an inherent consequence of bilateral double taxation conventions'; ${ }^{38}$ the benefit laid down in the DTC 'cannot be regarded as a benefit separable from the remainder of the Convention, but is an integral part thereof and contributes to its overall balance.' 39

Of course these arguments cannot be extrapolated to cases in which no DTC is at stake ${ }^{40}$ and, specifically, to those like Columbus in which the provisions involved are unilateral deviations of treaties. ${ }^{41}$ Therefore, the rejection of MFN by the ECJ does not clarify the problem of horizontal comparability.

And hence, we come to the issue in relation to which horizontal pairs of comparison have been admitted by the ECJ. We are referring to Cadbury Schweppes concerning the compatibility of the British CFC rules with the fundamental freedoms. ${ }^{42}$ It is true that the admission of horizontal comparability is not explicit in the ruling ${ }^{43}$ or at least 'as explicit' as that contained in the Opinion of AG Léger in the case. ${ }^{44}$ This might be the reason that several scholars reject the very existence of horizontal comparison in Cadbury Schweppes. ${ }^{45}$ Nevertheless, in our opinion, ${ }^{46}$ besides a traditional comparison between a cross-border situation and a domestic situation, Cadbury Schweppes introduces a more original comparison between two crossborder situations (horizontal):

Even taking into account, as suggested by the United Kingdom, Danish, German, French, Portuguese, Finnish, and Swedish Governments, the fact referred to by the national court that such a resident company does not pay, on the profits of a CFC within the scope of application of that legislation, more tax than that which would have been payable on those profits if they had been made by a subsidiary established in the United Kingdom, the fact remains that under such legislation the resident company is taxed on profits of another legal person. That is not the case for a resident company with a subsidiary taxed in the United Kingdom or a subsidiary established outside that Member State which is not subject to a lower level of taxation. ${ }^{47}$

It is true that, in cases referred to the principle of free choice of legal form in inbound situations, Cadbury Schweppes could be resolved on the basis of both vertical and horizontal comparability. Nevertheless, there is a significant difference: as against cases like Avoir Fiscal, Saint Gobain, and CLT-UFA, in Cadbury Schweppes, there is an explicit recognition of horizontal pairs of comparison.

On the other hand, it is not entirely clear whether the two parts of the comparison criteria used by the Court in Cadbury Schweppes and Cadbury Schweppes Overseas are to be applied individually or cumulatively. In other words,

\section{Notes}

36 Case No. C-376/03, D. v. Inspecteur van de Belastingdienst (hereinafter 'D.'), and Case No. C-374/04, Test Claimants in Class IV of the ACT Group Litigation v. Commissioners of Inland Revenue (hereinafter 'ACT').

37 Cordewener (2007), n. 2, 211.

38 Case No. C-376/03 D., para. 61; Case No. C-374/04 ACT, para. 91.

39 Case No. C-376/03 D., para. 62; Case No. C-374/04 ACT, para. 88.

40 Lang (2006), n. 29, 399; Hohenwarter, n. 16, 101, but in relation to Cadbury Schweppes.

41 Haslinger, 'Switch-Over bei Veräußerungsgewinnen aus internationalen Schachtelbeteligungen', Steuer und Wirtschaft International (2005), 175; Cordewener \& Schnitger, n. 18, 50; Cordewener (2007), n. 2, 212.

42 Case No. C-196/04, Cadbury Schweppes.

43 Hohenwarter indicates that the reasoning is 'less pronounced': Hohenwarter, n. 16, 101

44 Léger states: 'Unlike the United Kingdom, I do not see why Cadbury's situation should not be compared to that of such a company. I take the view that the assessment of the compatibility with Community law of the legislation in question must examine all the ramifications of that legislation. As we know, "discrimination" is defined as the application of different rules to comparable situations or the application of the same rule to different situations. The only question to be asked in order to determine whether different treatment of two situations is discriminatory is therefore whether those two situations are comparable. I take the view that that is the case in respect of Cadbury's position and that of a resident company which has established a subsidiary in another Member State having a less favourable tax regime than that in effect in the International Financial Services Centre because, in either case, a United Kingdom resident company has established a subsidiary in another Member State' (Opinion of AG Léger of 2 May 2006, C-196/04 Cadbury Schweppes, para. 78).

45 Kessler \& Eicke, n. 13, 589; Kemmeren, n. 16, 576.

46 This has been also stated by several authors: Hohenwarter, n. 16, 101; Cordewener (2007), n. 2, 211; CFE, 5; Cordewener (2008), n. 2, 226-227; Lang (2008), n. 2, 687. This is contained in AG Mengozzi's Opinion, 29 Mar. 2007, C-298/05, Columbus Containers, para. 114.

47 Case No. C-196/04, Cadbury Schweppes, para. 45. 
the question could be raised as to whether a difference in treatment provided for by the national legislation of the taxpayer's Member State of residence, which applies solely between two cross-border situations, is sufficient in order to consider that a restriction on freedom of establishment exists. ${ }^{48}$ This is exactly the case in Columbus Container Services. Anyway, the legal background described in the former paragraph for horizontal comparability might give an answer for this question. This was in fact the solution offered by AG Mengozzi in his opinion. ${ }^{49}$

In short, we must conclude that, despite rejection of horizontal comparability in certain cases (principle of free choice of legal form in outbound situations and MFN), there seems to be a tendency for the ECJ to accept this pair of comparison, ${ }^{50}$ at least if we analyze the problem according to the foundations upon which Cadbury Schweppes was based.

\subsection{Justification Test}

Once we have concluded that a national provision such as that contained in paragraph 20(2) and (3) of the ASt G constitutes a restriction on the freedom of establishment provided for by the Treaty, since it is likely to deter German nationals from establishing themselves freely in another Member State of their choice, it is necessary to consider whether such a restriction can be justified. For this purpose, the arguments contained in Cadbury Schweppes would be of great use. Nevertheless, before analyzing possible justifications for the restriction on freedom of establishment, one should consider whether or not differences between Cadbury Schweppes and Columbus Container Services might justify a different approach.

\subsection{Cadbury Schweppes and Columbus Container Services:Are They So Different?}

It is undoubted there are important differences between Cadbury Schweppes and Columbus Container Services. Nevertheless, once the most important (no vertical comparability in Columbus Container Services) has been considered irrelevant in order to justify different solutions for both cases, disparities seem hardly acceptable. In short, the nonapplication of the ECJ's case law on anti-avoidance rules to a case such as Columbus Container Services is difficult to understand. ${ }^{51}$

As stated before, the ECJ did not consider in Columbus Container Services the possible application of its Cadbury Schweppes anti-avoidance doctrine, as the conclusion that the rules contained in the $A S t G$ did not constitute a restriction made it unnecessary. Nevertheless, some authors have tried to introduce grounds for the disparity.

In this line of thought, Meussen indicated that in Columbus Container Services, there is no specific CFC legislation at stake and therefore this is not a matter of deemed income but rather of the attribution of income on the basis of income generated through a tax-transparent entity. Accordingly, the Cadbury Schweppes arguments do not apply in this case. ${ }^{52}$ In our opinion, this reason for a different treatment is not to be shared for the following reasons.

It is a common assumption among European scholars that the rules contained in sections 20(2) and (3) of the German $A S t G$ are aimed at avoidance of the CFC rules. ${ }^{53}$ And even in some cases, they have been considered $\mathrm{CFC}^{54}$ or quasi-CFC rules. ${ }^{55}$ But second, and perhaps more important, it does not really matter if the rules contained in the $A S t G$ are qualified or not formally as CFC provisions. They must be considered anti-avoidance or anti-delocalization rules, and this might be enough in order to justify a scrutiny under Cadbury Schweppes principles.

There is a 'hidden difference' between Cadbury Schweppes and Columbus Container Services that might be influencing the ECJ's approach. It is a treaty override that gives rise to the potential restriction of a fundamental freedoms in Columbus Container Services, whereas in Cadbury Schweppes, the problem originated from domestic CFC legislation. There has been a traditional reluctance of the ECJ to consider the correlation between DTC's and European Law. In any case, this is a reluctance that might be considered superseded by a large list of (recent) rulings in which the ECJ considered DTC's provisions in connection with domestic rules in order to ascertain whether or not fundamental freedoms might have been restricted. ${ }^{56}$ The ECJ

\section{Notes}

48 AG Mengozzi's Opinion, 29 Mar. 2007, Case No. C-298/05, Columbus Containers, para. 119.

49 AG Mengozzi’s Opinion, 29 Mar. 2007, Case No. C-298/05, Columbus Containers, paras 118-122.

so Hohenwarter, n. 16, 101

51 In fact, a large number of authors have pleaded for it: CFE, 5-7; Cordewener (2008), n. 2: 228 et seq; Lang (2008), n. 2, 693; Farmer, n. 3, 107-108; de la Feria, 'Prohibition of Abuse of (Community) Law: The Creation of a New General Principle of EC Law through Tax', Common Market Law Review 45 (2008): 432.

52 Meussen Apr. (2008), n. 13, 172. This same argument might be found in a critical exposition in CFE, 7.

53 Wassermeyer \& Schönfeld, in Außensteuerrecht Kommentar (Flick, Wassermeyer \& Baumhoff) (Köln: Otto Schmidt, 1973/2007), at sec. 20 Anm. 65, Lfg. 58, Mai 2006. Opinion Statement of the CFE ECJ Task Force on ECJ Tax Case No. C-298/05, Columbus Container Services BVBA E Co v. Finanzamt Bielefeld-Innenstadt, 2. Kessler \& Eicke, n. 13,588 . Farmer, n. 3, 105.

54 Schnitger, 'German CFC Legislation Pending before the European Court of Justice - Abuse of the Law and Revival of the Most-Favoured-Nation-Clause?', EC Tax Review no. 3 (2006), 156; de la Feria (2008), n. 51, 431.

55 Pistone, 'Ups and Downs in the Case Law of the ECJ and the Swinging Pendulum of Direct Taxation', Intertax no. 4 (2008), 147.

56 See Gilly (Case No. C-336/96); Saint-Gobain (C-307/97); AMID (C-141/99); D. (C-376/03); Bouanich (C-265/04); Denkavit International BV, Denkavit France SARL (C-170/05); Amurta (C-379/05); Orange European Smallcup Fund (C-194/06); Deutsche Shell (C-293/06); Lidl Belgium (C-414/06); SEVIC (C-411/03); Cartesio (C-210/06) and Überseering (C-208/00). 
may not examine the relationship between a national measure and the provisions of a DTC, such as the Bilateral Tax Convention, since that question does not fall within the scope of Community law, but this does not mean that the Court is not entitled to consider if a DTC, or its override, restricts fundamental freedoms. Again, there is no ground for the disparity.

The conclusion seems to be clear. There are no significant differences between Cadbury Schweppes and Columbus Container Services. Therefore, the restriction described in the latter must be considered under the criteria of the former and specially taking into account the crucial concept of wholly artificial arrangements.

\subsubsection{Is the Restriction Justified in Columbus}

Before the referring court, the Finanzamt BielefeldInnenstadt and the German Government claimed that the relevant provisions of $A S t G$ were justified in order to counteract harmful tax competition, to prevent wholly artificial arrangements, and to safeguard the cohesion of the tax system. Once horizontal comparability has been admitted, the justification of a restriction in Columbus Container Services is not a difficult task. An excellent analysis of this issue might be found in the opinion of AG Mengozzi delivered on the case, which has found extensive acceptance in specialized literature. ${ }^{57}$

AG Mengozzi refused easily that the contested provisions could be justified under harmful tax competition considerations or the intention to preserve the cohesion of the national tax system.

In relation to the first hypothetical justification ground, AG Mengozzi indicated that the fact that the tax system at issue may be classified as state aid incompatible with the common market and that it is incumbent on the Commission, under the Treaty, to check such compatibility cannot therefore entitle a Member State to take unilateral measures against that system intended to counter its effects, which would infringe one of the fundamental freedoms provided for by the Treaty. ${ }^{58}$ In other words, there is no place for 'self-protection' under European Law. ${ }^{59}$

On the other hand, AG Mengozzi strongly criticized the very concept of cohesion, describing it as 'rather diffuse' or even 'mysterious' ${ }^{60}$ Member States have often relied on it in among other types of justification, often recognized as being overriding requirements for the purposes of the case law, such as the effectiveness of fiscal supervision, combating tax evasion or tax fraud, or even the loss of tax revenue, which does not, however, come under those requirements. Bearing this in mind, a possible justification for the rules contained in the $A S t G$ should be analyzed under the scope of anti-abuse provisions, where the very core of the AG's analysis of potential grounds for justification really lies. ${ }^{61}$

On this issue, AG Mengozzi elaborated its construction on the basis of the approach to CFC rules in Cadbury Schweppes. In that ruling, the ECJ accepted that a tax measure that restricts the exercise of a fundamental freedom may be justified if that measure has the specific purpose of precluding from a tax benefit wholly artificial arrangements whose purpose is to circumvent or escape the law of the Member State concerned. According to this, a tax measure (that is, CFC rules) cannot be considered proportioned if it excludes categorically and generally any allegedly artificial arrangement from the benefit of a tax advantage without allowing the national courts to make a case-by-case analysis taking account the particular features of each case (essentially referring to physical existence in terms of premises, staff, and equipment).

Applying these criteria to Columbus Container Services, AG Mengozzi stated that paragraph 20(2) and (3) of the $A S t G$ appeared to be based on an irrefutable presumption that a purely artificial arrangement exists when the conditions referred to in that provision are met. ${ }^{62}$ Such an approach seems to be disproportionate to the objective pursued.

Following previous rulings, the AG confirmed that it was up to the national court to determine whether the German provisions allowed a case-by-case analysis. However, he insisted on the necessity of considering the level of employment of Columbus Containers in Belgium ${ }^{63}$ and rejected the fact that a company involved in activities with regard to holding and managing capital would not engage in actual economic activities in the host Member State. ${ }^{64}$

It is difficult to add something or refuse this approach. Under this premise, it is difficult to consider Columbus Container Services an artificial construction not integrated in its host state. ${ }^{65}$ The restriction does not seem justified.

\section{Notes}

57 CFE, 8; de la Feria (2008), n. 51, 431-432; Lang (2008) n. 2, 692-695; Cordewener (2008), n. 2, 230-232. Even those who reject horizontal comparability have to admit that if the Court had found that there was a restriction, there would have been good reason to assume that the restriction was not justified (Kessler \& Eicke, n. 13, 588).

58 AG Mengozzi’s Opinion, 29 Mar. 2007, C-298/05, Columbus Containers, para. 167. In the same sense, see AG Leger (paras 57-58) in his opinion on the case Cadbury Schweppes and AG Geelhoed (para. 63) in his opinion on the case ACT.

59 Lang (2008), n. 2, 693.

60 AG Mengozzi’s Opinion, 29 Mar. 2007, C-298/05, Columbus Containers, para. 190.

61 Cordewener (2008), n. 2, 231.

AG Mengozzi's Opinion, 29 Mar. 2007, C-298/05, Columbus Containers, para. 178.

AG Mengozzi’s Opinion, 29 Mar. 2007, C-298/05, Columbus Containers, para. 180.

AG Mengozzi's Opinion, 29 Mar. 2007, C-298/05, Columbus Containers, para. 181.

Cordewener (2008), n. 2, 232 


\section{The Consequences of Columbus Container Services}

This contribution would be unfinished if, leaving apart our critical perspective, we did not consider the consequences of this ruling for further developments in respect of highly disputed issues and in relation to company taxation in Europe. Of course, we have no capability of foretelling what the future will bring, specially when referring to rather strange and enigmatic rulings; nevertheless, we must be capable of inserting a judgment into the logical structure of previous rulings and using it to solve further problems. So, we will try to ascertain whether Columbus Container Services implies a change in relation to the traditional case law of the ECJ on anti-avoidance rules. As a final thing, we will briefly consider how Columbus Container Services might influence specific topics such as the principle of free choice of legal form in outbound situations.

\section{I. Is Cadbury Schweppes Overruled?}

One could consider that if the facts in Cadbury Schweppes and Columbus Container Services are pretty similar, the case law of the ECJ on anti-avoidance rules might have changed. Nevertheless, this might be a hasty conclusion, at least for CFC provisions, if we take into account latter pronouncements of the Court in relation to this kind of rules. In fact, and despite certain nuances, the ECJ has come back to Cadbury Schweppes in its recent Order of 23 April $2008^{66}$ in the case Test Claimants in the CFC and Dividend Group Litigation v. Commissioners of Inland Revenue. ${ }^{67}$ According to this, it seems more realistic to consider that Columbus Container Services has relaxed, to a certain extent, the strict requirements of its previous anti-abuse case law. The problem is to what extent and under which requirements.

A correct approach to the future significance of Columbus Container Services could imply making a distinction between strict anti-avoidance rules (such as CFC rules) and provisions merely aimed at capital export neutrality. The Member State's fiscal autonomy would be more limited in the former, which are only admitted under the 'wholly artificial arrangement' criterion. The latter measures might not be considered against EC Law if they do not imply different treatments for migrant and nonmigrant situations.

This approach could be a new sign of the compatibility of the credit method and capital export neutrality with EC Law and, to a certain extent, an explicit rider of Cadbury Schweppes that seemed to have sent a message in favour of the exemption method and the capital import neutrality. ${ }^{68}$ This reflection could display important consequences, for example, in relation to the switch-over clause introduced by the Working Group on the Common Consolidated Corporate Tax Base (CCCTB) for foreign income received by eligible companies resident in the EU that have opted for the CCCTB or by eligible companies not resident in the EU that have opted for the CCCTB in respect of their EU Pes. ${ }^{69}$ The very draft document produced by the Working Group declared unclear whether or not the switch-over clause could lawfully be applied to intra-EU dividends considering the Columbus Container Services case, which, at that time, was still unsolved..$^{70}$ Nevertheless, according to the decision of the ECJ in the case, most authors agree that a switch-over clause such as that introduced for CCCTB purposes does not form a restriction on the Treaty Freedoms. $^{71}$

In the same vein, the position of the ECJ in Columbus Container Services could help to reinforce the EU compatibility of domestic measures designed to combat tax competition within the EU, for instance, through the use of the credit method for double taxation relief. Likewise, one country could exclude the general application of the exemption method for double taxation relief when the foreign income is subject to a low level of taxation at source or when the income is characterized as passive income or when the activity that generates the foreign income was previously carried out in the home country by the same or a related taxpayer. In these cases, the application of the foreign tax credit instead of the exemption method pursues to neutralize (tax) advantages provided by Member States or to avoid the migration of companies (or the delocalization of economic activities) to the territory of Member States.

There is no doubt that the application of this kind of measures can generate restriction to the freedom of

\section{Notes}

66 C-201/05

67 In addition, the High Court of England and Wales ruled on 4 July 2008 in the case of Vodafone 2 in favour of a taxpayer who had to pay taxes according to the UK CFC rules for the profits of its Luxembourgian holding company. The principles of Cadbury Schweppes have been also applied in this ruling. See for this procedure Gnaedinger, 'Vodafone Wins Challenge Against CFC Law', Tax Notes International (Jul. 2008): 172-173, and Sykes, 'Vodafone 2 v. HMRC: The Roaming Boundaries of European Community Law', BTR no. 5 (2008): 536 et eq.

68 On the position of the ECJ on methods for avoiding double taxation, see Calderón Carrero \& Martín Jiménez, 'La jurisprudencia del TJCE en materia tributaria', Convenios fiscales internacionales y Fiscalidad de la UE (Valencia: CISS, 2008): 839 et seq. Cordewener \& Schnitger, n. 18: 50 et seq.

69 CCCTB/WP057/doc/en, CCCTB: Possible Elements of a Technical Outline (Brussels, 26 Jul. 2007), 31.

Ibid., n. 39.

1 Kofler, 'CFC Rules', in Common Consolidated Corporate Tax Base, eds Michael Lang et al. (Wien: Linde, 2008), 749; Weber \& Russo, 'The CCCTB and Possible Elements of a Technical Outline: The "Switch-Over" Clause', in Common Consolidated Corporate Tax Base, eds Michael Lang et al. (Wien: Linde, 2008), 768; Traversa, 'The CCCTB and Possible Elements of a Technical Outline: The "Switch-over" Clause', in Common Consolidated Corporate Tax Base, eds Michael Lang et al. (Wien: Linde, 2008), 783, with certain nuances. 
establishment, and when the principal goal of such measures is to prevent abusive arrangements, such measures would only be compatible with EC law if they are shaped in a proportionate way. However, it is far from clear whether or not the neutralization of advantages (of economic and tax nature) provided by other Member States could constitute a legitimate reason that would justify a restriction to a fundamental freedom.

In this context, we think that the use of the horizontal comparability analysis can be needed in order to establish the existence of a restriction to a fundamental freedom, as it occurred in Cadbury Schweppes. All in all, it seems that the ECJ jurisprudence tends to characterize this kind of measures that neutralize tax advantages but do not constitute anti-abuse rules in a strict sense, as quasi-restrictions that are not contrary to the EC Treaty.

This approach is not, however, exempt from problems. To distinguish between strict anti-avoidance rules and provisions merely aimed at capital export neutrality might not be an easy task. Switch-over clauses are, in fact, commonly qualified as anti-avoidance rules. And this is strictly related to the second problematic issue of this approach.

This simple distinction between anti-avoidance rules and provisions aimed at capital export neutrality goes perhaps too far because the ECJ does not discriminate among the latter measures. In this respect, provisions in line with capital export neutrality might be designed in a non-selective manner applying, for example, a switchover clause irrespective of the rate at which the income in question is taxed at source. But, as it is the case for the provisions contained in the $A S t G$, these measures can also be configured depending on a certain level of taxation in the host state. Nevertheless, the immediate consequence of the non-admission of horizontal pairs of comparison is considering both situations as not restrictive of fundamental freedoms. The question might be again whether or not selective and non-selective clauses deserve identical treatment. As stated before, a common market approach advises a different treatment. ${ }^{72}$
As has been said, the problem with the judgment is not what the Court says but what it does not say. ${ }^{73}$ By merely rejecting horizontal comparability, the ECJ judgment in Columbus Container Services not only lacks a proper foundation but also makes it difficult to predict its consequences.

\subsection{Free Choice of Legal Form in Outbound Situations: Classification of Foreign Entities}

Columbus Container Services has shed light on the scope of the principle of free choice of legal form under EU law requirements. Before the ruling, the application of the principle to outbound investments was highly disputed. On the one hand, and as described before, the ECJ had developed a vested case law on neutrality of legal form for inbound investments. On the other hand, some scholars defended the application of case law on recognition of legal form rules of other MS (in cases such as Centros Ltd v. Erbvervs- og Selskabsstyrelsen ${ }^{74}$ or Überseering and Inspire Art ${ }^{75}$ ) to tax matters. ${ }^{76}$ Despite it all, AG Mengozzi and the ECJ rejected the very existence of a principle of free choice of legal form in outbound investments using similar arguments:

At the current stage of development of Community law, it does not require Member States to recognize in their territory the legal and tax status afforded by the domestic law of the other Member States to entities which carry out their economic activities there ${ }^{77}$ it must be recalled that the fiscal autonomy... also means that the Member States are at liberty to determine the conditions and the level of taxation for different types of establishments chosen by national companies or partnerships operating abroad, on condition that those companies or partnerships are not treated in a manner that is discriminatory in comparison with comparable national establishments. ${ }^{78}$

The grounds for these statements might be different in both cases.

\section{Notes}

72 This is in our opinion the position defended by AG Mengozzi in Columbus: 'The unfavourable tax treatment in the present case does not result purely from application of the different tax legislations of the Member States, but from the choice made in the German tax legislation to set the mechanism for off-setting tax levied abroad on the income in question in motion where that tax is below the $30 \%$ level provided for by the AStG. It would be different in my view if the replacement of the exemption method by the set-off method, decided by the Federal Republic of Germany, applied irrespective of the rate at which the income in question was taxed in Germany. In that situation, any unfavourable treatment caused by application of that method to similar income of German taxpayers derived from permanent establishments located abroad would depend essentially on the level of tax levied in each of the Member States. It would in that case be unfavourable treatment arising from the coexistence of the different tax legislations of the Member States. However, that is certainly not the case here' (AG Mengozzi's Opinion, 29 Mar. 2007, C-298/05, Columbus Containers, paras 129-130).

3 Farmer, n. 3, 107.

74 Case No. C-212/97, Centros Ltd v. Erhvervs- og Selskabsstyrelsen. See also the SEVIC case (ECJ ruling of 13 Dec. 2005, C-411/03) and Cartesio (ECJ ruling of 16 Dec. 2008, C-210/06).

75 Case No. C-208/00, Überseering.

76 Fibbe \& Graaf, 'Is Double Taxation Arising from Autonomous Tax Classification of Foreign Entities Incompatible with EC Law?', in A Tax Globalist: The Search of the Orders of International Taxation: Essays in Honour of Maarten J Ellis, eds van Arendonk, Engelen \& Jensen (Amsterdam: IBFD, 2005): 478 et seq; Wassermeyer \& Schönfeld (2006), n. 53, at sec. 20 Anm. 58, Lfg. 58; Mai 2006.

7 AG Mengozzi's Opinion, 29 Mar. 2007, C-298/05, Columbus Containers, para. 41.

78 Case No. C-298/05, Columbus Container, para. 53. 
In relation to the ruling, the rejection of the principle of free choice of legal form is an immediate consequence of a strict migrant/non-migrant test approach. Under refusal of horizontal pairs of comparison, there is no place for a principle of free choice of legal form in outbound investments. Nevertheless, AG Mengozzi accepts horizontal comparability but also refuses a general EU requirement for the Member States to recognize legal and tax statutes afforded by other Member States. But this also seems to be logical. Using the very words of Mengozzi, the possible restriction on the freedoms of movement is not to be found in the classification of Columbus as a permanent establishment under German tax law. ${ }^{79}$ In short, it is not the switch-over clause or the rules on recognition of foreign entities that give rise to a restriction on the fundamental freedoms but its selective configuration (using the low-tax criterion of selectivity).
Whatever the reasons might be for this refusal, it might display significant consequences for several domestic provisions on classification of foreign entities or look-through rules passed in several Member States such as Germany, ${ }^{80}$ The Netherlands, ${ }^{81}$ or Spain. ${ }^{82}$ These rules could only be considered restrictive of fundamental freedoms if the companies or partnerships operating in other Member States are treated in a manner that is discriminatory in comparison with comparable national establishments. This would require the search of a domestic legal form that might be considered similar or equivalent to its foreign pair. Nevertheless, as international practice has showed, these comparisons might be a difficult task in many cases. ${ }^{83}$ Therefore, the existence of a restriction, even in the 'clear' approach of Columbus Container Services, might not be that evident and the consequences of the ruling in this field are far from predictable.

\section{Notes}

79 AG Mengozzi’s Opinion, 29 Mar. 2007, C-298/05, Columbus Containers, para. 45.

80 FIBBE, 'The (In)compatibility of the German LLC Decree on the Classification of Foreign Entities with the German Domestic Legal Framework and EC Law', European Taxation, Oct. (2006): 487 et seq.

81 Lamers \& Stevens, 'Classification of Foreign Entities and Classification Conflicts: Netherland's Developments', Intertax 33, no. 5 (2005): 240 et seq; Rademakers \& Swets, 'New Decrees on the Classification and Tax Treatment of Foreign (Hybrid) Entities in the Netherlands', European Taxation, May (2005): 171 et seg.

82 Delgado Pacheco, 'Las entidades en atribución de rentas y el régimen fiscal de partnerships y trusts en España', in Manual de Fiscalidad Internacional (Madrid: Instituto de Estudios Fiscales, 2007): 479 et seq. Bustos, Sánchez Gallardo, \& Seijo Pérez, Comunidades de Bienes. Entidades en atribución de rentas (Madrid: F. Lefevbre, 2004).

83 Fibbe (2006), n. 80: 487 et seq; Delgado Pacheco (2007), n. 82: 501 et seq. 